\title{
PENGEMBANGAN LEMBAR KEGIATAN PESERTA DIDIK (LKPD) BERBASIS INTRODUCTION, CONNECT, APPLY, REFLECT, EXTEND (ICARE) PADA POKOK BAHASAN SISTEM KOLOID
}

\section{DEVELOPMENT OF STUDENT ACTIVITIES WORKSHEET BASED ON ICARE OF COLLOID SYSTEM}

\author{
Destri Wahyuni", Rasmiwetti, dan Herdini \\ Program Studi Pendidikan Kimia, FKIP Universitas Riau, Indonesia \\ *Email : destiwahyuni39@gmail.com
}

Diterima: 14 Maret 2021. Disetujui: 24 Mei 2021. Dipublikasikan: 2 Juni 2021

\begin{abstract}
Abstrak: Penelitian yang telah dilakukan ditujukan guna mengembangkan Lembar Kegiatan Peserta Didik (LKPD) berbasis ICARE pada pokok bahasan sistem koloid untuk kelas XI SMA/MA sederajat. LKPD berbasis ICARE sebagai objek penelitian tersebut dirancang dan dikembangkan sesuai dengan tahapan model pembelajaran ICARE. Penelitian pengembangan ini mengacu pada model pengembangan 4-D. Instrumen pengumpulan data berupa lembar validasi dan angket respons pengguna. Luaran penelitian berupa LKPD berbasis ICARE dinyatakan valid berdasarkan aspek kelayakan isi, karakteristik ICARE, kebahasaan, penyajian, dan kegrafisan berturut-turut yaitu 89,81\%, 91,67\%, 95\%, 97,92\%, 100\%. LKPD berbasis ICARE diuji cobakan kepada guru kimia sebanyak 3 orang dan 20 orang peserta didik dengan perolehan persentase masing-masing sebesar $91,02 \%$ dan $80,96 \%$ berada pada kriteria sangat baik. LKPD berbasis ICARE yang dikembangkan telah valid dan dapat digunakan pada materi sistem koloid.
\end{abstract}

Kata Kunci: Sistem Koloid, ICARE, LKPD

\begin{abstract}
The research that has been carried out aims to develop an ICARE-based Participant Activities Sheet on the subject matter of the colloid system for grade eleventh senior high school. Student activities worksheet based on ICARE as the object of research is designed and developed by the stages of the ICARE learning model. This development research refers to the 4-D development model. The data collection instruments were validation sheets and user response questionnaires. The research output in the form of a student activities worksheet based on ICARE was declared valid based on content feasibility, ICARE characteristics, language, presentation, and graphics, respectively, namely $89.81 \%, 91.67 \%, 95.00 \%, 97.92 \%$, and $100 \%$. Three chemistry teachers validated the student activities worksheet. The 20 students were subject to a practicality test in which the respective percentages of $91,02 \%$ and $80,96 \%$ being outstanding criteria. The developed student activities worksheet based on ICARE has been valid and can be used on colloid system material.
\end{abstract}

Keywords: Colloid System, ICARE, Student Activities Worksheet

\section{PENDAHULUAN}

Segala sesuatu yang mutlak ada dan harus dipenuhi untuk meningkatkan kualitas diri masyarakat disebut dengan pendidikan. Pendidikan berkaitan dengan usaha yang dirancang untuk menimbulkan suasana belajar dan pembelajaran yang mengacu pada pengembangan potensi yang ada pada diri peserta didik [1]. Perubahan prilaku terjadi dengan adanya latihan atau pengalaman menjadi suatu hasil dari belajar [2]. Proses belajar mengajar tersebut mengacu pada kurikulum tertentu sesuai dengan kebijakan lembaga pendidikan setempat.

Kurikulum disusun dengan memperhatikan tahapan perkembangan peserta didik atau sesuai dengan jenjang masing-masing satuan pendidikan serta kesesuaiannya dengan perkembangan ilmu pengetahuan, lingkungan maupun teknologi dalam rangka mewujudkan tujuan pendidikan nasional [3]. Indonesia menerapkan kurikulum 2013 hingga saat ini. Salah satu upaya untuk menunjang keberhasilan penerapan kurikulum 2013 yaitu penggunaan media pembelajaran secara efektif pada proses pelaksanaan belajar mengajar, salah satunya bahan ajar.

Bahan ajar dapat diartikan sebagai bagian dari sumber ajar yang berisikan informasi tertulis ataupun tidak tertulis yang dirancang secara terstruktur sehingga dapat mempermudah tenaga pendidik dalam melaksanakan kegiatan pembelajaran [4]. Keberhasilan pencapaian pembelajaran juga dipengaruhi pada persiapan guru dalam mengelola kelas. Oleh karena itu, penggunaan bahan ajar maupun strategi pembelajaran yang tepat dapat mempengaruhi keberhasilan proses pembelajaran.

LKPD dapat berupa lembaran kertas yang memuat panduan atau kegiatan berisi tugas yang harus dikerjakan oleh peserta didik, sehingga memudahkan guru saat mengelola proses pembelajaran [5]. Penggunaan LKPD yang menarik diperlukan hampir untuk semua materi mata pelajaran sekolah, termasuk didalamnya pembelajaran kimia. Guru sebagai pendidik harus 
mampu merancang LKPD yang tepat dan mudah dipahami, namun kenyataannya masih banyak yang menggunakan bahan ajar instan tanpa upaya merancang, mendesain serta membuatnya sendiri [6].

Hasil dari wawancara peneliti terhadap guru kimia kelas XI MAN 2 Kampar dan SMA Muhammadiyah 1 Pekanbaru, didapatkan informasi bahwa guru sudah menggunakan LKPD, tetapi hanya pada materi yang bersifat eksperimen, sedangkan materi hitungan dan konsep, guru jarang menggunakan LKPD. Guru lebih sering menggunakan buku paket sebagai bahan ajar. LKPD yang digunakan guru masih memiliki kekurangan yaitu hanya difokuskan pada pencapaian pengetahuan saja dan LKPD dirancang juga belum dikembangkan dengan berbasis model pembelajaran, hanya berisi ringkasan materi, latihan soal serta tidak menggunakan desain maupun gambar yang menarik serta jarang dikaitkan dengan kehidupan sehari-hari. Selain itu, proses pembelajarannya masih didominasi dengan guru menjelaskan materi, kemudian memberikan soal. Oleh karena itu, diperlukan LKPD yang layak atau berkualitas sehingga dapat membentuk keterampilan menemukan, mengembangkan serta mengaplikasikan konsep yang dipelajari oleh peserta didik tersebut, yaitu menggunakan LKPD berbasis ICARE.

LKPD yang mencakup sintak ICARE dapat membantu peserta didik dalam menemukan, mengembangkan serta mengaplikasikan konsep materi. ICARE memiliki lima tahapan yaitu Introduction (pengenalan), Connect (menghubungkan), Apply (mengaplikasikan), Reflect (refleksi), serta Extend (melanjutkan) yang memberikan tekanan tertentu tiap tahapannya [7]. Salah satu kelebihan dari model pembelajaran ICARE adalah menuntut peserta didik agar dapat mengaplikasikan materi yang didapat dengan persoalan-persoalan nyata dikehidupan [8]. Sehingga peserta didik lebih memahami konsep yang sedang dipelajarinya tersebut.

Hasil penelitian terdahulu mengenai pengembangan LKS (Lembar Kegiatan Siswa) berbasis ICARE telah berhasil mencapai kualitas baik yang memenuhi 3 aspek yaitu praktis, valid serta efektif pada materi persamaan trigonometri kelas XI SMAN 17 Kota Makassar melalui metode ADDIE [9] Selain itu, penelitian yang membuktikan bahwa pengembangan LKPD yang disusun sesuai unsur-unsur model pembelajaran ICARE pada materi alat optik diperoleh persentase $84,2 \%$ dengan kategori sangat layak [10]. Pengembangan LKPD berbasis ICARE pada mata pelajaran kimia, khususnya materi sistem koloid belum tersedia, sehingga peneliti tertarik untuk melakukan penelitian pengembangan LKPD berbasis ICARE pada materi sistem koloid.

\section{METODE PENELITIAN}

Penelitian telah dilaksanakan di Program Studi Pendidikan Kimia FKIP Universitas Riau serta uji coba terbatas di SMA Muhammadiyah 1 Pekanbaru. Pengembangan LKPD berbasis model ICARE pada pokok bahasan sistem koloid dirancang menggunakan desain penelitian pengembangan (Research and Development), dimana penelitian ini menghasilkan produk tertentu yang dapat diuji keefektifannya [11]. Model pengembangan yang digunakan mengacu pada model pengembangan 4-D [12]. Model pengembangan 4-D memiliki kelebihan salah satunya sintak yang dijabarkan lengkap dan sistematis [13]. Selain itu, model pengembangan 4D juga melibatkan penilaian para ahli yang memberikan masukan dan saran sebelum dilakukan uji coba di lapangan. Namun, model pengembangan 4-D memiliki kekurangan yaitu belum terlihat jelas penepatan antara analisis tugas dan analisis konsep. Penelitian dilakukan hanya sampai pada tahap 3-D yaitu tahap Develop karena mengingat tujuan penelitian hanya untuk mengetahui pengembangan LKPD yang valid dan bagaimana respons penggunanya.

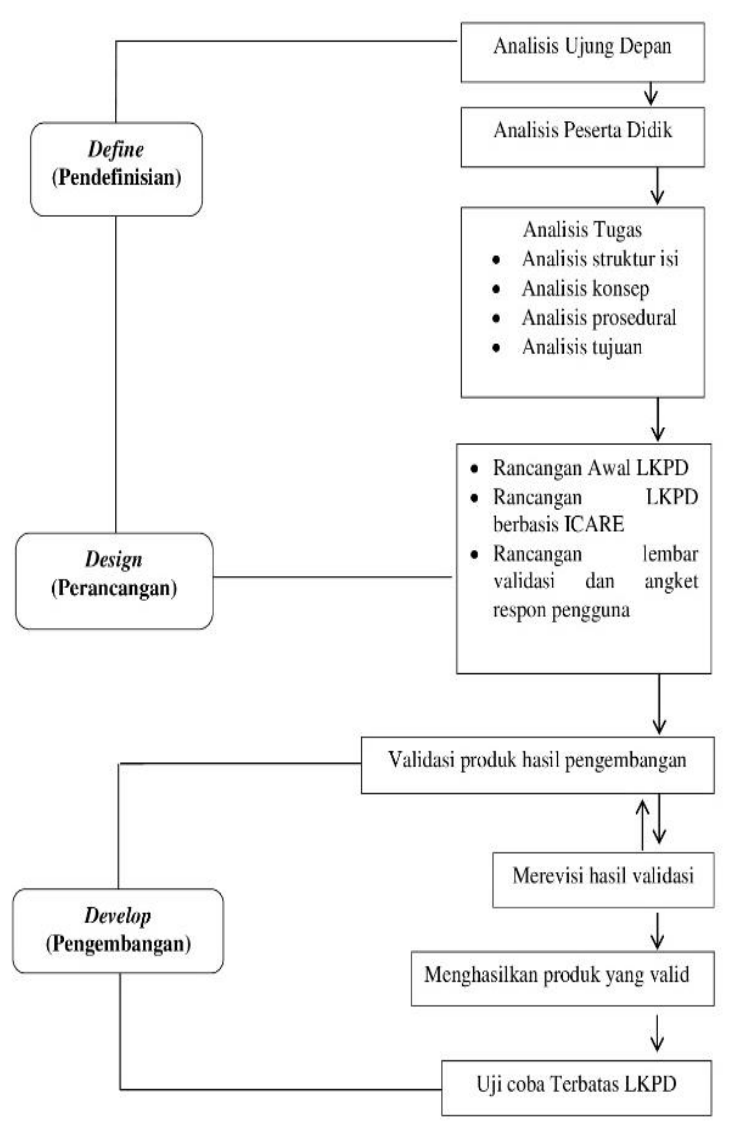

Gambar 1. Alur Pengembangan LKPD Berbasis ICARE pada Pokok Bahasan Sistem Koloid.

Teknik penelitian yang digunakan yaitu studi pustaka untuk memperoleh informasi teoritis dan studi lapangan untuk memperoleh data konkrit 
terkait penelitian yang dilakukan. Data hasil penelitian diperoleh dari tahap Develop meliputi proses validasi oleh 3 orang validator, revisi serta uji coba terbatas. LKPD berbasis ICARE pada pokok bahasan sistem koloid menggunakan instrumen penelitian berupa lembar validasi serta angket respon pengguna.

Data yang diperoleh kemudian dianalisis dengan analisis deskriptif untuk mendeskripsikan nilai hasil validasi pada setiap aspek yang diberikan oleh validator. Skala likert dengan skor 1-4 digunakan pada proses analisis data tersebut. Skor rata-rata dari setiap aspek validasi ditentukan persentasenya untuk melihat kelayakan LKPD yang telah dikembangkan, dengan cara berikut:

$$
\text { Persentase }=\frac{\text { Skor yang diperoleh }}{\text { Skor maksimum }} \times 100 \%
$$

Nilai persentase selanjutnya dikonversi kedalam nilai kualitatif seperti berikut:

Tabel 1. Kriteria Validitas [14]

\begin{tabular}{cl}
\hline Persentase & \multicolumn{1}{c}{ Keterangan } \\
\hline 80,00-100 & Valid/Layak/Baik \\
$60,00-79,99$ & Cukup Valid / Cukup \\
& Layak / Cukup Baik \\
$50,00-59,99$ & Kurang Valid / Kurang \\
& Layak / Kurang Baik \\
$0-49,99$ & Diganti (Tidak Baik) \\
\hline
\end{tabular}

Uji coba terbatas menggunakan angket yang terdiri dari beberapa pernyataan yang telah disusun oleh peneliti bertujuan untuk melihat respons atau tanggapan guru maupun peserta didik di lapangan terhadap kemudahan penggunaan LKPD berbasis ICARE. Hasil uji coba terbatas selanjutnya dianalisis menggunakan skala Likert dengan skor 1-4 dalam bentuk checklist $(\sqrt{ })$. Kategori penilaian ditunjukkan pada tabel 2 . Pemilihan skala Likert dilakukan karena tidak memberikan peluang bagi responden untuk bersikap netral.

Tabel 2. Kategori Penilaian oleh Pengguna [15]

\begin{tabular}{cc}
\hline Skor Penilaian & Kategori \\
\hline 4 & Sangat Setuju (SS) \\
3 & Setuju (S) \\
2 & Tidak Setuju (TS) \\
1 & Sangat Tidak Setuju
\end{tabular}

(STS)

Perolehan rata-rata dari hasil angket respons dihitung dengan cara berikut:

$$
\begin{gathered}
\text { Persentase }=\frac{\text { Skor yang diperoleh }}{\text { Skor maksimum }} \times 100 \% \\
\begin{array}{l}
\text { Kriteria dalam mengambil keputusan } \\
\text { respons atau tanggapan pengguna disajikan pada }
\end{array}
\end{gathered}
$$

tabel 3 .

Tabel 3. Kriteria Respons Pengguna [16]

\begin{tabular}{cc}
\hline Persentase & $\begin{array}{c}\text { Kriteria Respons } \\
\text { Pengguna }\end{array}$ \\
\hline $75,00-100$ & Sangat Baik \\
$50,00-74,99$ & Baik \\
$25,00-49,99$ & Kurang Baik \\
$0,00-24,99$ & Tidak Baik \\
\hline
\end{tabular}

\section{HASIL DAN PEMBAHASAN}

LKPD berbasis ICARE pada pokok bahasan sistem koloid menggunakan desain penelitian pengembangan atau lebih dikenal sebagai istilah Research and Development (R\&D) dengan model 4-D yang dimodifikasi menjadi 3-D (Define, Design, Develop). Berikut tahapan penelitian pengembangan LKPD berbasis ICARE:

\section{Tahap Pendefenisian (Define)}

Diawali dengan menentukan permasalahan mendasar dalam proses pembelajaran melalui analisis ujung depan. Analisis ujung depan telah dilaksanakan melalui berbagai literatur yang relevan dan pra-penelitian di sekolah melalui wawancara dengan guru kimia di SMA Muhammadiyah 1 Pekanbaru dan MAN 2 Kampar. Informasi yang diperoleh adalah terkait bahan ajar, kesulitan proses pembelajaran, materi maupun keterkaitan peserta didik terhadap bahan ajar. Bahan ajar yang sering digunakan di sekolah adalah LKPD dan buku paket. Melalui wawancara terstruktur juga diperoleh informasi bahwa guru sudah menggunakan LKPD khususnya yang bersifat eksperimen pada materi pembelajaran kimia, salah satunya pada materi sistem koloid. LKPD yang dibuat oleh guru belum memenuhi syarat-syarat yang harus dipenuhi dalam membuat LKPD. LKPD tersebut hanya berisi ringkasan materi, beberapa pertanyaan yang sulit membangun sendiri pengetahuannya sehingga membuat peserta didik lebih sulit memahami pembelajaran.

Analisis kedua yaitu analisis terhadap peserta didik kelas XI MIA SMA/MA karena sistem koloid merupakan materi semester genap untuk rentang usia 16-18 tahun. Uji coba terbatas dengan menggunakan angket respons pengguna dilakukan pada semester ganjil bulan Oktober 2021 di kelas XII MIA sehingga peserta didik telah memiliki pengetahuan mengenai materi sistem koloid.

Analisis ketiga yaitu analisis tugas yang diawali dengan menganalisis struktur isi yang meliputi kompetensi inti, kompetensi dasar dan materi sistem koloid. Kemudian dilanjutkan dengan menganalisis konsep yaitu konsep-konsep utama yang sesuai dengan kurikulum 2013 pada pokok bahasan sistem koloid yang akan dipelajari dalam LKPD. Hasil analisis ini diperoleh peta konsep 
materi sistem koloid yang disusun secara sistematis antar sub materi. Selanjutnya analisis prosedural berkaitan dengan tahapan-tahapan yang digunakan dalam penyelesaian LKPD. Tahapan yang digunakan berdasarkan model pembelajaran ICARE, terdiri dari 5 tahapan sesuai dengan singkatan ICARE yang pertama kali diperkenalkan di San Diego State Univerity yaitu Introduction, Connect, Apply, Reflect, Extend. Terakhir dilakukan perumusan tujuan pembelajaran yang dirumuskan berdasarkan pada KD dan IPK.

\section{Tahap Perancangan (Design)}

Perancangan LKPD menghasilkan komponen LKPD yang mancakup cover, judul LKPD, petunjuk belajar, KD, IPK, tujuan pembelajaran, materi, tugas atau kegiatan maupun tahap-tahap yang harus dikerjakan peserta didik, kolom penilaian serta daftar pustaka yang disajikan dengan paduan warna tertentu sehingga dapat meanrik perhatian dan minat peserta didik untuk membaca dan mengerjakan LKPD tersebut [17].

Pada tahap Design (perancangan) juga dirancang instrumen penilaian berupa lembar validasi serta angket uji respons pengguna. Selain itu, juga dirancang rubrik penilaian agar memudahkan responden dalam mengisi angket. Rancangan lembar validasi terdiri dari 5 aspek penilaian kelayakan.

\section{Tahap Pengembangan (Develop)}

Tahap Develop diawali dengan proses validasi LKPD dan uji coba terbatas untuk mengetahui kelayakan LKPD dan kriteria respons pengguna LKPD yang dikembangkan.
Validasi bertujuan untuk memperoleh penilaian dan saran terhadap LKPD berbasis ICARE pada materi sistem koloid oleh tim ahli materi dari 2 universitas berbeda yaitu dosen dari UNRI sebanyak 2 orang dan 1 orang dosen UMRI. Proses validasi telah dilakukan sebanyak dua kali. Data hasil penilaian pada validasi pertama dan kedua dianalisis berdasarkan masing-masing aspek validasi. Diagram rata-rata validasi kedua yang telah dilakukan terdapat pada gambar 2 .

Rata-rata persentase total untuk kelima aspek kelayakan validasi pertama yakni sebesar $85,94 \%$ dan validasi kedua yakni $94,88 \%$. Nilai kelayakan tersebut berada pada rentang kriteria validitas 80,00-100 dengan kategori valid, sehingga dapat dilakukan uji coba. Hal ini sejalan dengan penelitian yang telah dilakukan oleh Suryanti dan Muh. Asrullah yang berhasil mengembangkan LKPD berbasis ICARE pada materi trigonometri [8]; Abdul Hamid, $d k k$ juga mampu membuktikan bahwa LKPD berbasis ICARE pada alat optik layak digunakan dalam proses pembelajaran [9]; serta penelitian oleh Endah Tri Handayani juga membuktikan bahwa pengembangan LKPD berbasis ICARE pada materi penentuan perubahan entalpi berada pada kategori sangat baik [18-20].

Berdasarkan hasil validasi tersebut validator menilai bahwa LKPD berbasis ICARE pada pokok bahasan koloid dapat membantu peserta didik dalam menemukan, menghubungkan maupun mengaplikasikan koloid kedalam persoalan-persoalan nyata yang ditemui di kehidupan sehari-hari melalui tahapan tiap sintak yang runtut serta sistematis.

\section{Diagram Persentase Validitas II Berbagai Aspek Oleh Validator Materi}

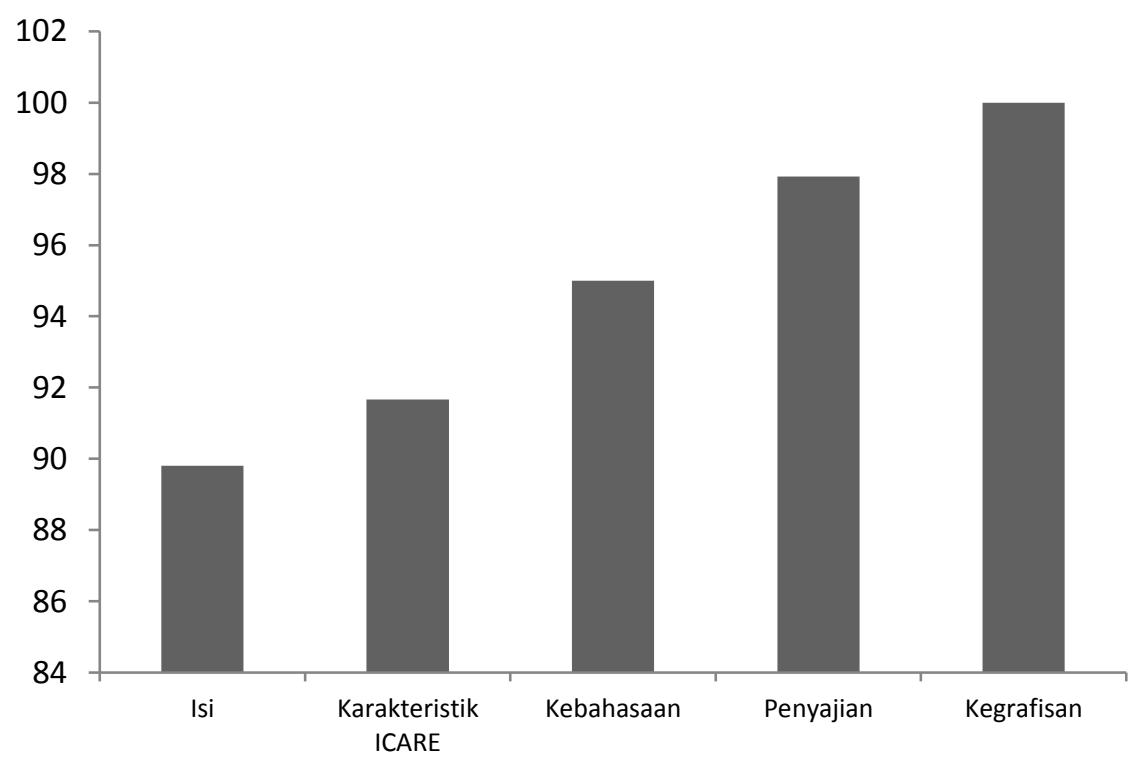

Gambar 2. Persentase Penilaian Validasi II 
LKPD yang telah dinyatakan valid diuji coba satu-satu (one to one evaluation) kepada 3 orang peserta didik dari latar belakang kemampuan yang berbeda-beda. Dalam pengerjaannya, setiap peserta didik membutuhkan waktu yang berbedabeda untuk menyelesaikan LKPD berbasis ICARE. Peserta didik pada umumnya dapat mengerjakan tahapan-tahapan pada LKPD, namun terdapat beberapa soal yang jawabannya masih keliru. Hal ini disebabkan karena ada beberapa soal yang kurang efektif dari sisi aspek kebahasaan serta maknanya kurang dipahami oleh pengguna LKPD. Selain itu, dapat juga disebabkan oleh peserta didik terlalu terburu-buru maupun kurang teliti dalam menyelesaikan tiap kegiatan dalam LKPD, bahkan tidak memeriksa kembali jawaban yang telah dikerjakan.

Uji coba selanjutnya dilakukan kepada guru kimia sebanyak 3 orang dan 20 orang peserta didik untuk mengetahui respons dari sisi pengguna LKPD. Pada hasil uji coba ini, LKPD telah diperbaiki sesuai komentar dari pengguna untuk penyempurnaan LKPD. Hasil respons guru yang diperoleh persentase rata-rata sebesar 91,02\% (sangat baik) dan hasil peserta didik diperoleh nilai persentase rata-rata $80,96 \%$ (sangat baik), sehingga hasil uji coba terbatas ialah LKPD memiliki respons sangat baik sebagai instrumen pembelajaran.

\section{KESIMPULAN}

LKPD berbasis model ICARE pada pokok bahasan sistem koloid untuk kelas XI SMA/MA memperoleh hasil bahwa validisi pada aspek kelayakan isi, karakteristik ICARE, kebahasaan, penyajian dan kegrafisan berturut-turut yaitu $89,81 \%, 91,67 \%, 95 \%, 97,92 \%, 100 \%$ berada pada kategori valid. Hasil uji respons pengguna oleh 20 orang peserta didik dan 3 orang guru kimia termasuk ke dalam kriteria sangat baik dengan masing-masing persentase sebesar $91,02 \%$ dan $80,96 \%$. Berdasarkan hasil data tersebut disimpulkan bahwa LKPD berbasis model ICARE dinyatakan valid serta dapat digunakan pada proses pembelajaran kimia di kelas.

\section{UCAPAN TERIMA KASIH}

Ucapan terima kasih disampaikan kepada Proyek AKSI ADB Universitas Riau Tahun 2020.

\section{DAFTAR PUSTAKA}

[1] Sanjaya, W. (2019). Strategi pembelajaran berorientasi standar proses pendidikan. Jakarta: Kencana Prenada Media Group.

[2] Irianti, M., Zulirfan, Z., \& Zaini, A. (2007). Pembelajaran Sains Fisika melalui Pendekatan SETS (Science Environment Technology Society) pada Siswa Kelas VIII MTs Nurul Falah Air Molek. Jurnal Geliga Sains: Jurnal Pendidikan Fisika, 1(2), 1-7.
[3] Hamalik, O. (2001). Proses belajar mengajar. Jakarta: Bumi Aksara.

[4] Triyono (2013). Metodologi Penelitian Pendidikan, Yogyakarta: Ombak.

[5] Nasional, K. P. (2010). Panduan Pengembangan Bahan Ajar. Jakarta: Direktorat Jenderal Manajemen Pendidikan Dasar dan Menengah, Departemen Pendidikan Nasional.

[6] Andi, P. (2012). Panduan Kreatif Membuat Bahan Ajar Inovatif Menciptakan Metode Pembelajaran yang Menarik dan Menyenangkan. Yogyakarta: DIVA Press.

[7] Jusuf, R., Sopandi, W., Wulan, A. R., \& Sa'ud, U. S. (2019). Strengthening Teacher Competency through ICARE Approach to Improve Literacy Assessment of Science Creative Thinking. International Journal of Learning, Teaching and Educational Research, 18(7), 70-83.

[8] Mahdian, M., Almubarak, A., \& Hikmah, N. (2019). Implementasi model pembelajaran ICARE (Introduction-Connect-Apply-ReflectExtend) terhadap keterampilan proses sains pada materi larutan elektrolit dan non elektrolit. Jurnal Penelitian Pendidikan IPA, 5(1).

[9] Djainuddin, S., \& Asrullah, M. (2019, December). Pengembangan Lembar Kerja Siswa (LKS) Berbasis ICARE pada Materi Persamaan Trigonometri Kelas XI. In PROSIDING Seminar Nasional FKIP Universitas Muslim Maros (Vol. 1, pp. 159164).

[10] Hamid, A., Ngadimin, N., \& Azwi, N. (2020). The Development of Student Worksheet to Support ICARE Learning Model on Optical Equipment Material. Asian Journal of Science Education, 2(1), 56-63.

[11] Sugiyono. (2012). Metode Penelitian Kuantitaif, Kualitatif, dan $R \& D$. Bandung: Alfabeta.

[12] Trianto. (2012). Mendesain Model Pembelajaran Inovatif- Progresif. Jakarta: Kencana Prenada Media Group.

[13] Trianto. (2007). Model Pengembangan Terpadu dalam Teori dan Praktek. Surabaya: Pustaka Ilmu.

[14] Riduwan. (2012). Skala Pengukuran VariabelVariabel Penelitian. Bandung: Alfabeta.

[15] Sugiyono. (2016). Metode Penelitian Kuantitatif, Kualitatif, dan $R \& D$. Bandung: Alfabeta.

[16] Yamasari, Y. (2010). Pengembangan media pembelajaran matematika berbasis ICT yang berkualitas. In Seminar Nasional Pascasarjana X-ITS, Surabaya (Vol. 4).

[17] Sastrawan, E., \& Yenti, E. (2020). Desain Dan Uji Coba Lembar Kerja Peserta Didik (Lkpd) Terintegrasi Islam pada Materi Kimia 
Unsur. JEDCHEM (JOURNAL EDUCATION AND CHEMISTRY), 2(1), 8

[18] Ningthias, D. P., Siahaan, J., \& Purwoko, A. A. (2018). Pengaruh Model Quantum Learning Menggunakan Lks Terhadap Hasil Belajar Siswa Kelas Xi Sman 2 Mataram. Jurnal Pijar Mipa, 13(2), 100-105.

[19] Handayani, E. T. (2021). Pengembangan LKPD Berbasis ICARE (Introduction, Connect, Apply, Reflect, Extend) pada Materi Penentuan Perubahan Entalpi Untuk SMA/MA. Journal of Research and Education Chemistry, 3(1), 1-1.

[20] Fauziah, N., Hakim, A., \& Andayani, Y. (2019). Meningkatkan literasi sains peserta didik melalui pembelajaran berbasis masalah berorientasi green chemistry pada materi laju reaksi. Jurnal Pijar MIPA, 14(2), 31-35. 